\title{
EFFECTS OF MONOLAYERS MADE FROM DIFFERENT EMULSIONS ON SURFACE WATER EVAPORATION IN A TYPICAL ALGERIAN OASIS
}

\author{
Sofiane Saggaï*1, Djamel Boutoutaou ${ }^{2}$ and Oum Elkheir Bachi ${ }^{3}$ \\ ${ }^{1}$ University KASDI MERBAH Ouargla, Laboratory ofWater and Environment \\ Engineering in Saharan Milieu (GEEMS). \\ ${ }^{2}$ University KASDI MERBAH Ouargla, Laboratory of Exploitation and Valorization of \\ Natural Resources in Arid Zones (EVRNZA). \\ ${ }^{3}$ University of Kasdi Merbah Ouargla. Laboratory of Saharan Bio-resources: \\ Preservation and Valorization (BRS). \\ *Corresponding author: Sofiane Saggaï \\ sofianeaero@yahoo.fr
}

(Received September 2015- Accepted June 2018)

\begin{abstract}
Saggaï, S. Boutoutaou, D. and Elkheir Bachi, O. 2018. Effects of monolayers made from different emulsions on surface water evaporation in a typical Algerian oasis. Lebanese Science Journal. 19(3): 400-409.

The extremely high rate of evaporation from surface water bodies in arid and semi-arid regions greatly reduces optimal utilization of water reservoirs. Therefore, techniques to reduce evaporation are greatly needed. During the last decades, a large number of dams (68 dams) were constructed and distributed over the entire country. Hence, preserving and protecting the stored water by reducing evaporation is strategic future task of the Algerian state. Experiment was conducted in Touggourt during summer with four Colorado evaporation pans and weather station. Two fatty alcohols emulsion were selected and applied to reduce the evaporation in different pans. The first pan $(O P)$ was filled with water without adding emulsion, while in the second pan $\left(P 2\right.$, Hexa) Hexadecanol emulsion was added at the concentration of $0.15 \mathrm{~g} / \mathrm{m}^{2}$. For the third pan (P3, Hexa/Octa) a mixture of Hexadecanol/Octadecanol emulsion was added at the same concentration (0.075g Hexa: $0.075 \mathrm{~g}$ Octa) and for the fourth pan (P4, Octa) Octadecanol emulsion was added with a concentration of $0.15 \mathrm{~g} / \mathrm{m}^{2}$. The different formulations and concentrations were repeated on the respective water surface every three days in order to form a monolayer.
\end{abstract}

http://dx.doi.org/10.22453/LSJ-019.3.400409 National Council for Scientific Research - Lebanon 2018® 1sj.cnrs.edu.lb/vol-19-no-3-2018/ 
Daily observations during 33 days showed that films reduced water losses by evaporation and the rates of evaporation reduction were significant and amounted $22.2 \%$ for $P 2,22.5 \%$ for $P 3$ and $16.2 \%$ for P4. In addition, water losses by evaporation were observed to be affected by temperature and $\mathrm{pH}$ of water.

Keywords: water, evaporation, fatty alcohols, water temperature, $\mathrm{pH}$.

\section{INTRODUCTION}

Fresh water resources such as groundwater and surface water in the form of streams and lakes have strategic importance and high economic value for a country. They become even vital when they are scarce and non-renewable particularly in arid regions.

Algeria, due to its geographical location and climatic conditions, is characterized by limited renewable water resources. In fact, renewable water resources of Algeria are significantly less than non-renewable water resources due to the low annual precipitation and therefore, require greater attention for development and management for long term utilization.

Considering the importance of optimal utilization of renewable water resources, the Ministry of Water Resources has constructed 68 dams and several new dams are under construction (Terra, 2013).

One of the challenges of water management in arid regions is to reduce the huge amount of water loss through evaporation from water surfaces of open water storages due to extremely high evaporative demand.

The rainfall in Algeria takes place primarily during winter and spring. However, appreciable summer rain does occur in some parts of Algeria. The ambient air temperature varies greatly from season to season and from region to region. Very high temperatures combined with extreme diurnal variation occur throughout Algeria. July has the maximum temperature over most of Algeria. The lowest relative humidity is generally noted during June and July whereas December and January are the months of maximum relative humidity. Relative humidity of less than $30 \%$ is very common during the summer months (N.O.M.A, 2013).

The dominant climatic features in Touggourt study area are high mean air temperature, low relative humidity and hot winds, resulting in relatively high evaporation rates. The climate is very hot in summer (June-August) with maximum air temperature exceeding $44^{\circ} \mathrm{C}$ and is very cold in winter (December-February) with minimum air temperature of $12^{\circ} \mathrm{C}$ (N.O.M.A, 2013). During summer months evaporation rates from water surface may reach their peak up to $20 \mathrm{~mm} / \mathrm{day}$. In order to reduce the evaporation from water surfaces several methods are used and they are 
described by Craig (2008), GHD Pvt Ltd (2003) and CEESU and RWUEI (2002).

After a detailed review of the available evaporation reduction methods, surface water cover technique was selected using fatty alcohol emulsion substance to form a thin film over water surface to reduce evaporation. This method has several advantages over others (Herzig et al, 2011). It is economically feasible due to low cost of substance and easily available.

There are several methods to measure evaporation from free water surface through Colorado pan, or more accurately by using the energy balance equation (Craig, 2008). Due to several factors including air movement and fluctuation of water surface, which affect the accuracy of measurement of evaporation depth therefore, standard and well recognized method of Colorado pan was selected for our study.

The present pilot study was conducted to measure the reduction of evaporation on relatively small and controlled water surface of four pans (Colorado pan) with continuous measurement of air temperature, relative humidity, wind speed (at $2 \mathrm{~m}$ high) and evaporation rates and evaluate the results in terms of efficiency in reducing evaporation.

\section{MATERIALS AND METHODS}

The pilot study was conducted at Touggourt, $\left(33^{\circ} 06^{\prime} 00^{\prime \prime} \mathrm{N}, 6^{\circ} 04^{\prime} 00^{\prime \prime} \mathrm{E}\right)$ south-east of Algeria, during summer (from 04/07/2012 to 05/08/2012). In this season, the evaporation rates reach the maximum (more than $12 \mathrm{~mm} /$ day (N.O.M.A., 2013)) values due to high air temperature and low relative humidity. The Colorado evaporation pans were of one square meter surface and half meter deep, and were partially buried and placed one near each other keeping $50 \mathrm{~cm}$ separation and covered by wire mesh to prevent animals from drinking water.

Different amounts of fatty emulsion were applied to the surface water in evaporation pans. A control pan with no added substance (OP) was used to measure evaporation rate under the prevailing weather conditions. In the second pan (Hexa), Hexadecanol, emulsion at the concentration of $0.15 \mathrm{~g} / \mathrm{m}^{2}$ was applied on water surface. For the third pan (Hexa/Octa), emulsion of mixture of Hexadecanol and Octadecanol at the concentration of $0.15 \mathrm{~g} / \mathrm{m}^{2}$ was applied on water surface; the quantity of each fatty alcohol was $0.075 \mathrm{~g}$. The fourth pan (Octa) Octadecanol emulsion with concentration of $0.15 \mathrm{~g}$ was applied on the water surface. All formulations were put on the respective water surface every three days, in order to form a monolayer.

Weather parameters were taken from standard weather station which is situated in the Touggourt airport and they including air temperature, relative humidity, wind speed and sunshine hours as well as water levels, water temperature and $\mathrm{pH}$ in four pans were daily measured. 


\section{Statistical analysis}

Data of evaporation rates water temperatures and $\mathrm{pH}$ were presented as means \pm standard deviation. Different experimental groups were compared either with the one-way ANOVA followed by Honest Significant Difference (HSD) test of Tukey for comparisons post hoc. A probability level of $\mathrm{P}<0.05$ was considered to be statistically significant. The STATISTICA software package (STATISTICA Ver. 6.0, 2001) was used for all tests.

\section{RESULTS AND DISCUSSION}

\section{Evaporation rates and weather parameters}

It is well known that the combination of high temperatures low humidity and dry winds create the strongest conditions for evaporation from open water (Coop, 2011 and Remini, 2005).

During the experiment, maximum air temperature was between $34.4{ }^{\circ} \mathrm{C}$ and 47.7 ${ }^{\circ} \mathrm{C}$ with an average of $42.9{ }^{\circ} \mathrm{C}$, while the wind speed was between $0.4 \mathrm{~m} / \mathrm{s}$ and $5.5 \mathrm{~m} / \mathrm{s}$ with an average of $2.8 \mathrm{~m} / \mathrm{s}$. The minimum relative humidity ranged from $9 \%$ to $27 \%$ with an average of $14.9 \%$ and sunshine duration was of 387.4 hours. For the daily pan evaporation rates, they were between $9 \mathrm{~mm} /$ day and $17 \mathrm{~mm}$ /day with an average of $12.5 \pm 2.2 \mathrm{~mm}$ in pan (OP), while daily pan evaporation rates were $10.5 \pm 1.6 \mathrm{~mm} /$ day in pan (Octa), $9.8 \pm 1.4 \mathrm{~mm} /$ day in pan (Hexa) and $9.7 \pm 1.8 \mathrm{~mm} /$ day in pan (Hexa/Octa).

Figure 1 shows that the evaporation rate was maximum in the pan (OP) which means that the presence of monolayers in the other evaporation pans at the air-water interface reduced the evaporation rates. This observation has been reported by Saggai and Boutoutaou $(2012,2011)$. 


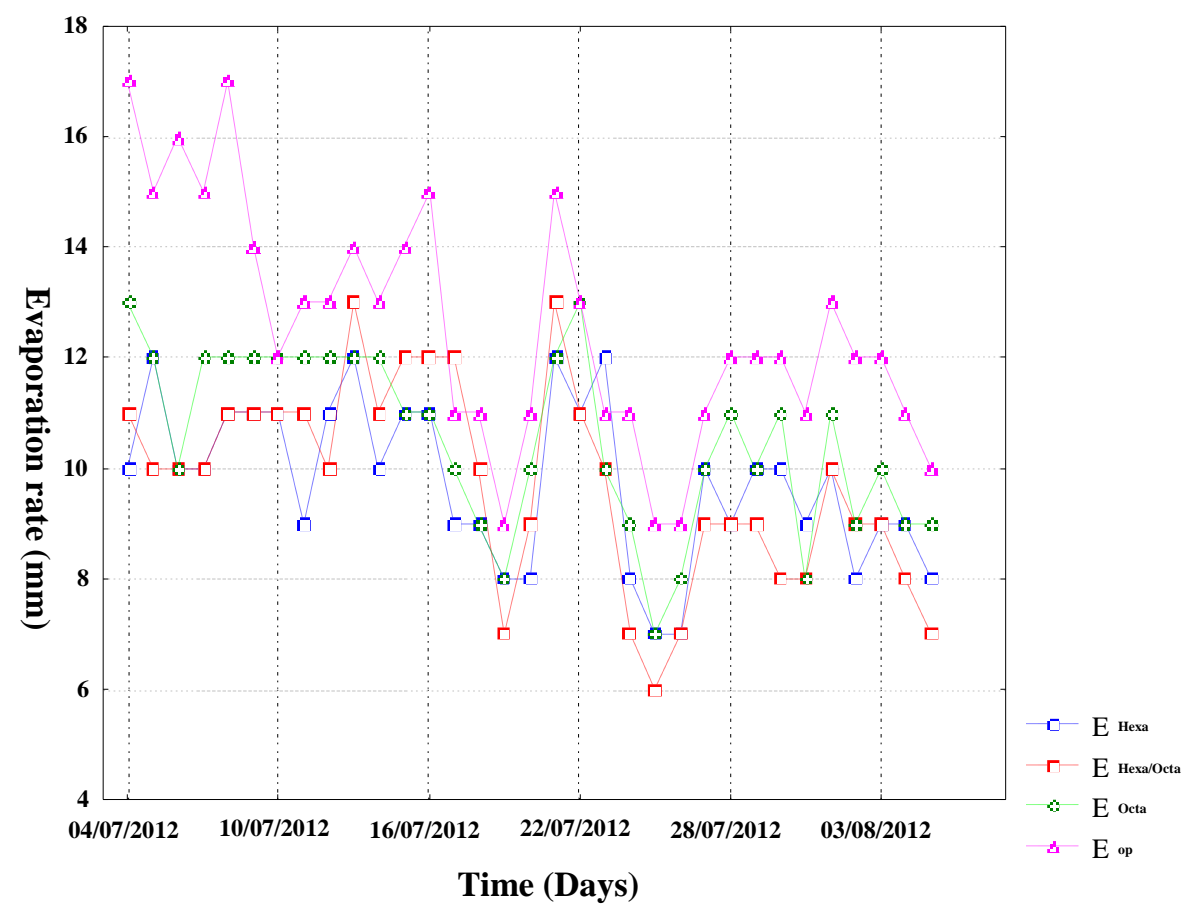

Figure 1. Daily losses due to evaporation in the four pans ( $\mathrm{mm})$ over 33 days.

Statistically, the analysis of Table 1shows that there were significant differences in evaporation rates between the control and the other evaporation pans. But comparing the evaporation rates measured on pans with monolayers no significant differences were observed (all values of $\mathrm{p}$ are more than 0.05 ).

Table 1. Test HSD Tukey; variable "Evaporation" (the mean difference is significant at the 0.05 level).

\begin{tabular}{|l|l|l|l|l|}
\hline Evaporation & $\begin{array}{l}(1) \mathrm{M}=9.8 \\
\mathrm{~mm}\end{array}$ & $\begin{array}{l}(2) \mathrm{M}=9.7 \\
\mathrm{~mm}\end{array}$ & $\begin{array}{l}(3) \mathrm{M}=10.5 \\
\mathrm{~mm}\end{array}$ & (4) $\mathrm{M}=12.5 \mathrm{~mm}$ \\
\hline $\begin{array}{l}\text { E Hexa } \\
(1)\end{array}$ & - & 0.999879 & 0.301434 & 0.000008 \\
\hline $\begin{array}{l}\text { E } \\
\text { Hexa/Octa(2) }\end{array}$ & 0.999879 & - & 0.267280 & 0.000008 \\
\hline $\begin{array}{l}\text { E Octa } \\
(3)\end{array}$ & 0.301434 & 0.267280 & - & 0.000025 \\
\hline $\begin{array}{l}\text { E OP } \\
(4)\end{array}$ & 0.000008 & 0.000008 & 0.000025 & - \\
\hline
\end{tabular}

Evaporation reduction (ER) rates which represent the saved water in the covered pans are calculated by the following equation (1): 


$$
E R=(\text { E op/E monolayers pans }) * 100
$$

Where:

ER: Evaporation Reduction rate in percentage (\%);

E op: Evaporation rate in the control pan $(\mathrm{mm})$; and

E monolayers pans: Evaporation rate in the fatty alcohols monolayers pans (Hexa, Hexa/Octa and Octa) (mm).

The calculated rates of evaporation reduction were: $22.2 \%$ in pan (Hexa), $22.5 \%$ in pan (Hexa/Octa) and $16.2 \%$ in pan (Octa).

It is well documented that monolayers with two components can have interesting and potentially useful properties (Barnes, 2008). According to Gugliotti et al. (2005) and McArthur and Durham (1957), Octadecanol added to Hexadecanol yielded a mixture with a good spreading rate and a higher evaporation resistance than pure Hexadecanol which explains the obtained results.

\section{Water temperatures}

Evaporation reduction was accompanied by a water temperature increase (Figure 2). Water temperatures of the experimental period in the four pans were: $33.3 \pm 1.3^{\circ} \mathrm{C}$ in the pan (OP), $35.5 \pm 1.1^{\circ} \mathrm{C}$ in the pan (Octa), $35.6 \pm 1.0^{\circ} \mathrm{C}$ in the pan (Hexa) and $35.4 \pm 1.7^{\circ} \mathrm{C}$ in the pan (Hexa/Octa).

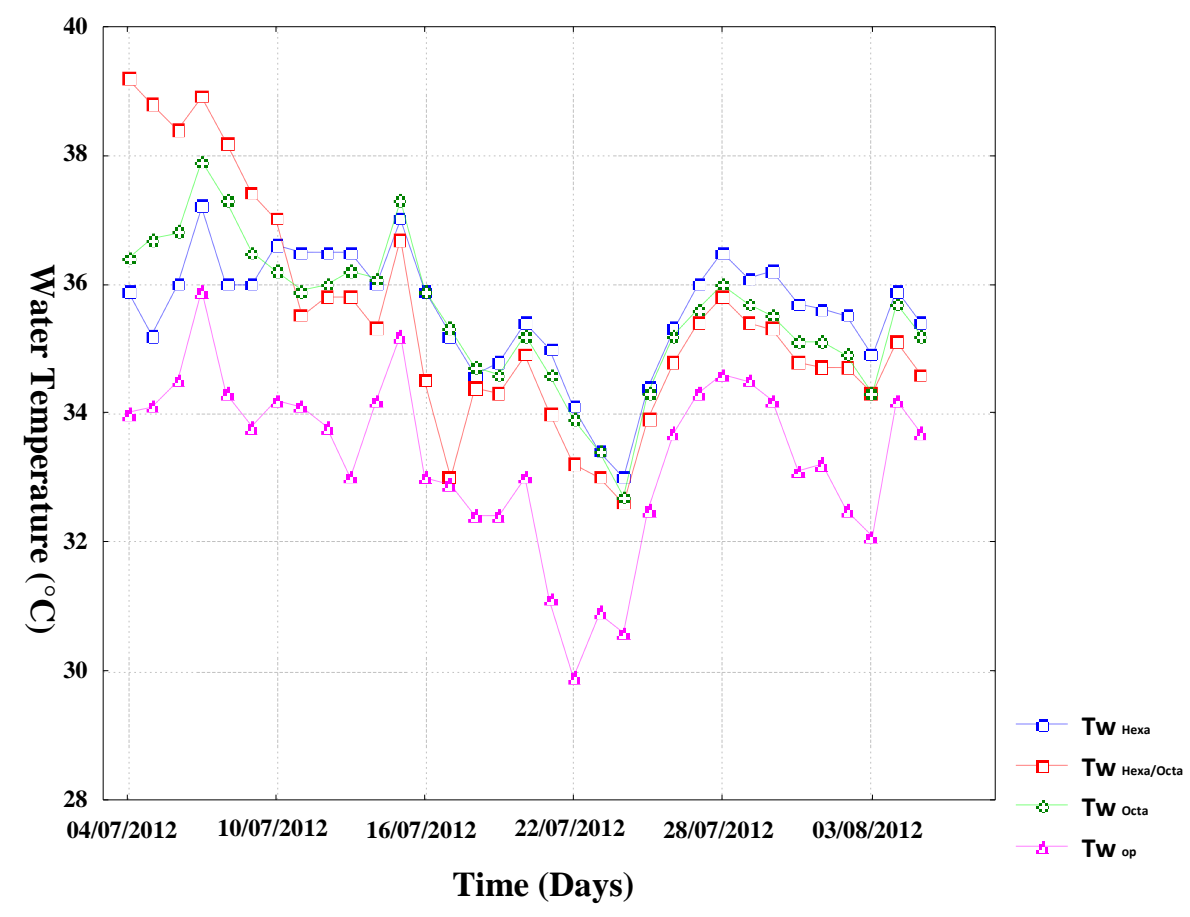

Figure 2. Daily water temperature in the four pans ( $\mathrm{mm})$ over 33 days. 
Simple comparisons with one-way ANOVA statistical analysis followed by HSD test of Tukey (Table 2) shows that there are significant differences between water temperatures registered from clear surface water compared to that registered from the water surfaces covered by monolayers. But comparing water temperatures registered in the cases of monolayers it is seen that there is no significant difference (all values of $p$ are more than 0.05). This analysis confirms that monolayers have a significant effect on water temperature.

Table 2. Test HSD Tukey; variable "Water Temperature" (the mean difference is significant at the 0.05 level).

\begin{tabular}{|l|l|l|l|l|}
\hline $\begin{array}{l}\text { Water } \\
\text { temperature }\end{array}$ & $(1) \mathrm{M}=35.6^{\circ} \mathrm{C}$ & $(2) \mathrm{M}=35.4^{\circ} \mathrm{C}$ & $(3) \mathrm{M}=35.2^{\circ} \mathrm{C}$ & $(4) \mathrm{M}=33.3^{\circ} \mathrm{C}$ \\
\hline $\begin{array}{l}\text { Tw Hexa } \\
(1)\end{array}$ & - & 0.973896 & 0.997380. & 0.000008 \\
\hline $\begin{array}{l}\text { Tw } \\
\text { Hexa/Octa(2) }\end{array}$ & 0.973896 & - & 0.995606 & 0.000008 \\
\hline $\begin{array}{l}\text { Tw Octa } \\
(3)\end{array}$ & 0.997380 & 0.995606 & - & 0.000008 \\
\hline $\begin{array}{l}\text { Tw OP } \\
(4)\end{array}$ & 0.000008 & 0.000008 & 0.000008 & - \\
\hline
\end{tabular}

Evaporation requires energy and leads to cooling of the water surface. The presence of a monolayer reducing the evaporation rate would therefore reduce the extent of surface cooling (Barnes, 2008).

Jarvis et al. (1957) reported that the surface water temperatures with and without monolayer differed by up to $4^{\circ} \mathrm{C}$, and that is what we have found but with difference of up to $2^{\circ} \mathrm{C}$.

\section{Hydrogen ion concentration}

Hydrogen ion concentration $(\mathrm{pH})$ was also checked during experiments. Continuous control of $\mathrm{pH}$ in open water storages aims to determine if water is in need of treatment and if so what is the level of the needed treatment? (Rejdek, 2002).

Hydrogen ion concentration of the experimental period in the four pans was: $8.18 \pm 0.09$ in the pan (OP), $8.07 \pm 0.10$ in the pan (Octa), $8.10 \pm 0.12$ in the pan (Hexa) and $8.11 \pm 0.11$ in the pan (Hexa/Octa). By observing these results and figure 3 , it would appear that $\mathrm{pH}$ was relatively high in the control pan (OP) compared to $\mathrm{pH}$ in pans with monolayers and that continuous film would not detrimentally affect the hydrogen ion concentration of water within the basic $\mathrm{pH}$ range of 8.07 to 8.18 . 


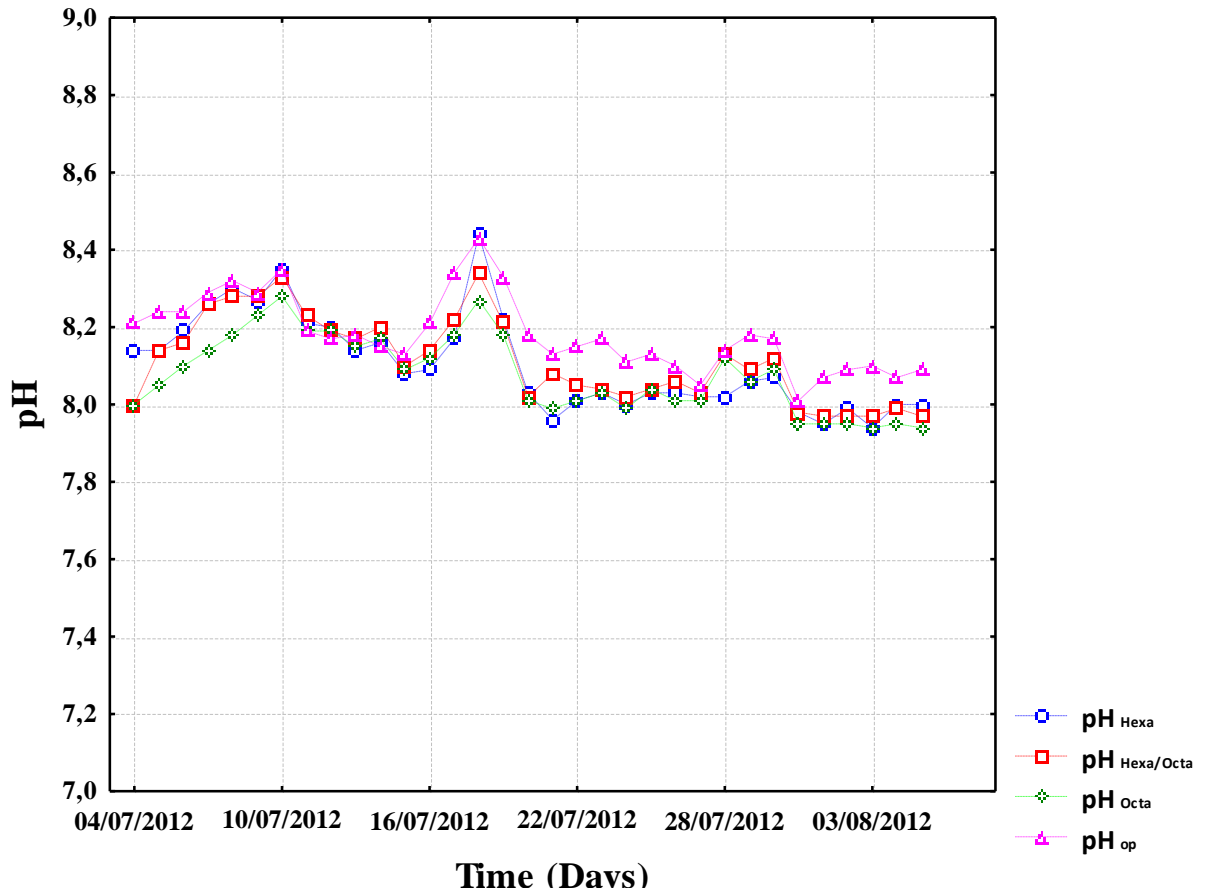

Figure 3. Daily Hydrogen ion concentration in the four pans ( $\mathrm{mm})$ over 33 days.

Saggai et al. (2013), Craig et al. (2005) and Wixson (1966) experiments have shown no significant changes in hydrogen ion concentration with and without monolayers. Statistically, the presence of Hexadecanol and Octadecanol monolayers have a significant effect on $\mathrm{pH}$ (Table 3 ).

Table 3. Test HSD Tukey; variable "pH" (the mean difference is significant at the 0.05 level).

\begin{tabular}{|c|c|c|c|c|}
\hline $\mathrm{pH}$ & (1) $M=8.10$ & (2) $M=8.11$ & (3) $M=8.07$ & (4) $\mathrm{M}=8.18$ \\
\hline pH Hexa & - & 0.986791 & 0.729192 & 0.023048 \\
\hline pH Hexa/Octa(2) & 0.986791 & - & 0.517133 & 0.058763 \\
\hline pH Octa & 0.729192 & 0.517133 & - & 0.000627 \\
\hline $\mathrm{pH}$ OP & 0.023048 & 0.058763 & 0.000008 & - \\
\hline
\end{tabular}

\section{Impact of monolayer on water environment}

The effects of application of monolayers and surface films on water quality are largely unknown. Some researchers believe that the effects of monolayers on aquatic processes are relatively benign due to the fact that most water bodies already have naturally occurring microlayers that are formed by the breakdown of organic material (Norkrans, 1980).

Wixon (1966) had undertaken the effect of monolayers of mixture Hexadecanol 
and Octadecanol on water quality and found that relative to the clean water surface, applying the monolayer reduced oxygen diffusion by $10 \%$ to $15 \%$ caused some filamentous algae and increased bacterial population. According to Saggaî et al (2013) under laboratory conditions the presence of monolayers of Hexadecanol on water surface of Tilapia aqua system does not affect the physical and chemical quality of water except dissolved oxygen rate which differs and becomes lower; concerning biological parameters, the monolayer of Hexadecanol is not toxic but its presence reduces the rate of Tilapia growth.

\section{CONCLUSION}

Numerous laboratory and field studies to date have shown that the use of the long-chain alcohols, Hexadecanol and Octadecanol, as monolayers reduces evaporation rates of water and rises water temperatures.

For the $\mathrm{pH}$, studies have reported that the presence of monolayers on water surface has no effect on hydrogen ion concentration.

Statistically, the analysis of gathered experiments data has shown a significant effect of monolayers on evaporation reduction rates and on water temperatures for all the covered pans.

In the case of hydrogen ion concentration and contrary to what it was reported by lot of authors, the statistical study has shown a significant effect in cases of monolayers of pure Hexadecanol and pure Octadecanol. For the monolayers of mixture of Hexa/Octa there was no significant effect.

\section{ACKNOWLEDGEMENTS}

This research was funded by the laboratory of Exploitation and Valorisation of natural resources in arid zones. The authors would like to thank Mr. Hamou Hicham.

\section{REFERENCES}

Barnes, G. T. 2008. The potential for monolayers to reduce the evaporation of water from large water storage, Agricultural Water Management, 95: 339 - 353.

CEESU \& RWUEI. 2002. Current knowledge and developing technology for controlling evaporation from on-farm storages. Ntional Program for Irrigation Research and Development, Department of Natural Resources and Mines, Queensland, Australia.

Coop, P. A. 2011. Detection of Evaporation Reducing Monolayers on Open Water Surfaces. PhDThesis, University of New England.

Craig, I., Green, A., Scobie, M. \& SchmidT. E. 2005. Controlling Evaporation Loss from Water Storages. National Centre for Engineering in Agriculture Publication 
1000580/1, USQ, Toowoomba. 207 pp.

Craig I. P. 2008. Loss of storage water through evaporation with particular reference to arid and semiarid zone pastoralism in Australia. Desert Knowledge CRC Working paper 19: The WterSmart ${ }^{\mathrm{TM}}$ Literature Reviews, Desert Knowledge. 60 pp.

GHD Pvt Ltd. 2003. Methods for reducing evaporation from storages used for urban water supplies. Final Report, Department of Natural Resources and Mines, Australia, No. 41/12219/67346.

Gugliotti, M., Baptista, M. S., \& Politi, M. J. 2005. Reduction of evaporation of natural water samples by monomolecular films. Journal Brazilian chem. Soc., 16(6A), 1186-1190.

Herzig, M. A. BARNES G.T. and GENTLE I.R. 2011. Improved spreading rates for monolayers applied as emulsions to reduce water evaporation. Journal of Colloid and Interface Science, 357: 239-242.

Jarvis, N. L., Timmons, C. O., \& Zisman, W. A. 1962. The effect of monomolecular films on the surface temperature of water. In: La Mer, V.K. (Ed.) Retardation of Evaporation by Monolayers: Transport Processes. Academic Press, New York.

Mcarthur I. K. H., \& Durham K. 1957. Fatty alcohols for water conservation. In: Proceedings of the Second International Congress of Surface Activity London, 1: 262-269.

N.O.M.A. 2013. Meteorological data. National office Meteorological Agency.

Norkrans, B. 1980. Surface microlayers in aquatic environments. Advances in Microbial Ecology, 4: 51- 85.

Rejsek, F. 2002. Analyse des eaux: Aspects réglementaires et techniques. Centre régional de documentation pédagogique d'Aquitaine, Bordeaux. $36 \mathrm{pp}$.

Remini, B. 2005. L'évaporation des lacs de barrages dans les régions arides et semi arides : exemples algériens. Larhyss Journal, 4 : 81-89.

Saggai, S., \&Boutoutaou, D. 2011. Réduction de l'évaporation des plans d'eau par les films mono-moléculaires en zones arides (cas de HASSI BENABDELLAH). Annales des Sciences et Technologie, 3(2): 114-118.

Saggai, S., \& Boutoutaou, D. 2012. Evaporation reduction of water plans in arid zones by monomolecular films (case of Ouargla). In: Proceedings of the 16th International Water Technology Conference, 7-10 May 2012, Istanbul.

Saggai, S., Saggai, M. M., \& Hancock, N. 2013. Laboratory study of the effect of Hexadecanol monolayer on the aquatic fauna (case of Tilapia nilotica). Revue des BioRessources, 3(2) : 1-7.

Terra M .2013. Les réalisations de l'Algérie dans le secteur de l'eau de 1962 à 2012. Communication presented by M Terra Director at Ministry of Water Resources, february 14th, 2013 Tamanrasset.

Wixson, B., (1966). Studies on the ecological impact of evaporation retardation monolayers. Texas Water Resources Institute Technical Report 6: Texas. 101pp. 